\title{
Reason Treatment Not Administered
}

National Cancer Institute

\section{Source}

National Cancer Institute. Reason Treatment Not Administered. NCI Thesaurus. Code C102704.

The reason the treatment was not administered. 